\title{
Oligocene magnetostratigraphy from Equatorial Pacific sediments (ODP Sites 1218 and 1219, Leg 199)
}

\author{
Luca Lanci $^{\text {a,b,c,* }}$, Josep M. Parés ${ }^{\text {d }}$, James E.T. Channell ${ }^{\mathrm{e}}$, Dennis V. Kent ${ }^{\mathrm{c}, \mathrm{f}}$ \\ a Istituto di Dinamica Ambientale, Università di Urbino, Urbino, PU 61029, Italy \\ b Alpine Laboratory of Paleomagnetism, V. Madonna dei Boschi, Peveragno, CN, Italy \\ ${ }^{\mathrm{c}}$ Department of Geological Sciences, Rutgers University, Piscataway, NJ 08854, USA \\ ${ }^{\mathrm{d} D e p a r t m e n t ~ o f ~ G e o l o g i c a l ~ S c i e n c e s, ~ U n i v e r s i t y ~ o f ~ M i c h i g a n, ~} 2534$ C.C. Little Building, Ann Arbor, MI 48109, USA \\ ${ }^{\mathrm{e}}$ Department of Geological Sciences, University of Florida, 241 Williamson Hall, Gainesville, FL 32611, USA \\ ${ }^{\mathrm{f}}$ Lamont-Doherty Earth Observatory, Palisades, NY 10964, USA
}

Received 17 February 2005; received in revised form 19 June 2005; accepted 4 July 2005

Available online 3 August 2005

Editor: V. Courtillot

\begin{abstract}
An Oligocene magnetostratigraphy from ODP Sites 1218 and 1219 (Equatorial Pacific) has been obtained by measurements made on u-channel samples, augmented by about 221 discrete samples. U-channel samples were measured at $1 \mathrm{~cm}$ intervals and were stepwise demagnetized in alternating fields (AF) up to a maximum peak field of $80 \mathrm{mT}$. The magnetization directions were determined at $1 \mathrm{~cm}$ intervals by principal component analysis of demagnetization steps in the 20 to $60 \mathrm{mT}$ peak field range. A similar treatment was carried out on the discrete samples, which confirmed the results obtained with u-channel measurements. Sites 1218 and 1219 were precisely correlated based on multisensor track, paleontological and shipboard magnetostratigraphic data; this correlation is substantiated by u-channel measurements. Although the magnetostratigraphy obtained from the u-channels is similar to the interpretation deduced from shipboard measurements based on blanket demagnetization at peak $\mathrm{AF}$ of $20 \mathrm{mT}$, the u-channel results are substantially more robust since many interpretative uncertainties are resolved by the stepwise demagnetization and higher stratigraphic resolution. The temporal resolution of u-channel-based magnetic stratigraphy in the Oligocene section of Sites 1218 and 1219 is better than $5 \mathrm{kyr}$, and it is therefore suitable for detection of brief polarity subchrons. However, in spite of the high resolution, we did not find any reversals corresponding to the numerous cryptochrons identified in this time span by Cande and Kent [S.C. Cande, D.V. Kent, Revised calibration of the geomagnetic polarity time scale for the Late Cretaceous and Cenozoic, J. Geophys. Res. 100 (1995) 6093-6095].
\end{abstract}

(C) 2005 Elsevier B.V. All rights reserved.

Keywords: Oligocene; magnetostratigraphy; Equatorial Pacific; cryptochrons; Ocean Drilling Program

* Corresponding author. Facoltà di Scienze Ambientali, Università di Urbino, Campus Scientifico SOGESTA, Urbino, PU 61029, Italy. Tel./fax: +39722304295 .

E-mail address: 1lanci@uniurb.it (L. Lanci).

0012-821X/\$ - see front matter (C) 2005 Elsevier B.V. All rights reserved. doi:10.1016/j.eps1.2005.07.004 


\section{Introduction}

Ocean Drilling Program (ODP) Leg 199, "The Paleogene Equatorial Transect" (Sites 1215 through 1222), was designed to study the evolution of the equatorial Pacific current and wind systems, as the Earth went from maximum Cenozoic warmth to initial Antarctic glaciations [2]. The drilling program was primarily devoted to collecting samples along a transect on 56- to 57-Ma crust, which is old enough to capture the Palaeocene/ Eocene boundary in the basal, more carbonaterich, sediments.

Sediment cores from Leg 199 were recovered using the ODP advanced piston corer (APC) and undisturbed sediments that retain an excellent record of the past Earth's magnetic field were obtained $[3,4]$. Our data can be used to reconstruct geomagnetic reversal history, thereby providing an age model and a tool for regional and global correlation. The APC coring was effective for sampling these unconsolidated sediments with minimum disturbance; moreover it allowed the cores to be azimuthally oriented for recovery of paleomagnetic declination information. Core orientation is essential to identify the magnetic polarity at near-equatorial latitudes where the paleomagnetic inclination is close to horizontal for both normal and reverse polarity intervals.

Cores from Sites 1218 and 1219 are the targets of this study. The upper $100 \mathrm{~m}$ of ODP Site 1218 gave a detailed magnetostratigraphy of the entire Miocene [3] and demonstrated that it is possible to resolve polarity chrons as short as $5-10 \mathrm{kyr}$. In the Oligocene part of the section, the sediment accumulation rate was higher than in the Miocene and allows us to obtain an even higher temporal resolution. Therefore, besides providing an important dating and correlation tool, the high-resolution reversal record from Sites 1218 and 1219 gives detailed information about the behaviour of Earth's magnetic field. The Oligocene, in particular, constitutes an interesting time interval because of the presence of many apparently short polarity "events" that have been hypothesized based on low amplitude (25-100 nT), short wavelength $(8-25 \mathrm{~km})$ sea surface magnetic anomalies measured over fast spreading oceanic crust. These small features, dubbed "tiny wiggles" by LaBrecque et al. [5], can be correlated among ocean basins and have been recognized as a high-resolution record of the paleomagnetic field [6,7]. Their origin is uncertain since they can be interpreted either as periods with low paleointensity and/or as short polarity chrons. In acknowledgement of their uncertain origin, they have been referred to as "cryptochrons" [8].

The origin of cryptochrons remains controversial. Although a few tiny wiggles have been recognized as true polarity subchrons, such as the Cobb Mountain subchron $[9,10]$ and the Réunion subchron $[11,12]$, the origin of many of them remains elusive. Lanci and Lowrie [13] proposed that they do not represent brief polarity chrons based on magnetostratigraphic results in chrons $\mathrm{C} 13 \mathrm{n}$ to $\mathrm{C} 16 \mathrm{n}$ from the Massignano section (Italy). One (of three) cryptochrons within $\mathrm{C} 13 \mathrm{r}$ appears as a brief polarity subchron (C13r.1n) in ODP Site 1090 in the South Atlantic [14]. Three cryptochrons were interpreted to correspond to brief subchrons within Late Miocene Chron C5n.2n [15-17]. However, Krijgsman and Kent [18] found the same 3 features recorded in single samples in Deep-Sea Drilling Project Site 608 in the North Atlantic and interpreted them as directional excursions, most likely associated with decreases in paleointensity. These brief subchrons have not been recognized in other magnetostratigraphic records covering the same stratigraphic interval [19].

To identify very short polarity intervals, continuous and undisturbed sedimentary records are needed, such as those of ODP Sites 1218 and 1219. A relatively large number (18) of cryptochrons are reported in the GPTS from Cande and Kent [1] (hereafter referred to as CK95) to occur in the time span considered in our study of chrons $\mathrm{C} 6 \mathrm{Cr}$ to $\mathrm{C} 13 \mathrm{n}$. The durations of the hypothetical polarity intervals associated with the "tiny wiggles" have been estimated at around $20 \mathrm{kyr}$ [8]; thus, if cryptochrons represent short polarity subchrons it should be possible to detect them in the records from Sites 1218 and 1219 . We present data from the lower 100 $\mathrm{m}$ of APC cores from Site 1218, that combined with about $30 \mathrm{~m}$ of APC cores from Site 1219, provide a high-resolution record of Oligocene geomagnetic reversal stratigraphy. 


\section{Materials and sampling}

\subsection{Drilling sites}

ODP Site $1218\left(8^{\circ} 53.378^{\prime} \mathrm{N}, 135^{\circ} 22.00^{\prime} \mathrm{W}\right.$, water depth of $4811 \mathrm{~m}$ ) is situated on a basement swell $\sim 300 \mathrm{~km}$ north of the Clipperton Fracture Zone in the central tropical Pacific [2,3] (Fig. 1). Site 1219 $\left(7^{\circ} 48.02^{\prime} \mathrm{N}, 142^{\circ} 0.94^{\prime} \mathrm{W}\right.$, water depth of $\left.5063 \mathrm{~m}\right)$ is the southernmost site drilled during Leg 199 and is located about $750 \mathrm{~km}$ from Site 1218. Only two holes were drilled at this site. Hole 1219A was cored using the APC to about $225 \mathrm{~m}$ below sea floor (mbsf), recovering sediments suitable for magnetostratigraphy from the Lower Oligocene and Upper Eocene and including the Eocene/Oligocene boundary. Hole 1219B was aborted when an APC core jammed in the bottom-hole assembly at about the depth of the Eocene/Oligocene boundary $(\sim 155$ mbsf) and hence the sediment record from Site 1219 below this depth is not complete due to core gaps.
Nevertheless, Site 1219 could be correlated to Site 1218 by means of shipboard magnetostratigraphic and multi-sensor track physical properties data $[2,20]$.

The Pleistocene and Miocene sediments at Site 1218 comprise two main sedimentary units [2]. The upper $59 \mathrm{~m}$ consists of a Pleistocene to Middle Miocene brown clay unit with some nannofossils and occasional barren intervals [2,3]. This upper clay unit is mostly made of wind-blown dust, clays, and radiolarians, some of which were reworked from older outcropping sediment. Below this brown clay unit, from 59 to $242 \mathrm{~m}$ composite depth, the section comprises nannofossil ooze and chalk of Lower Miocene-Oligocene age, which is the subject of this paper.

The sediment column at Site 1219 consists of $30 \mathrm{~m}$ of clay (lithologic Unit I) that overlies OligoceneLower Miocene nannofossil ooze (Unit II; 30-151 mbsf). The Oligocene sediments sampled at both sites consist of a nannofossil ooze/chalk unit (Unit

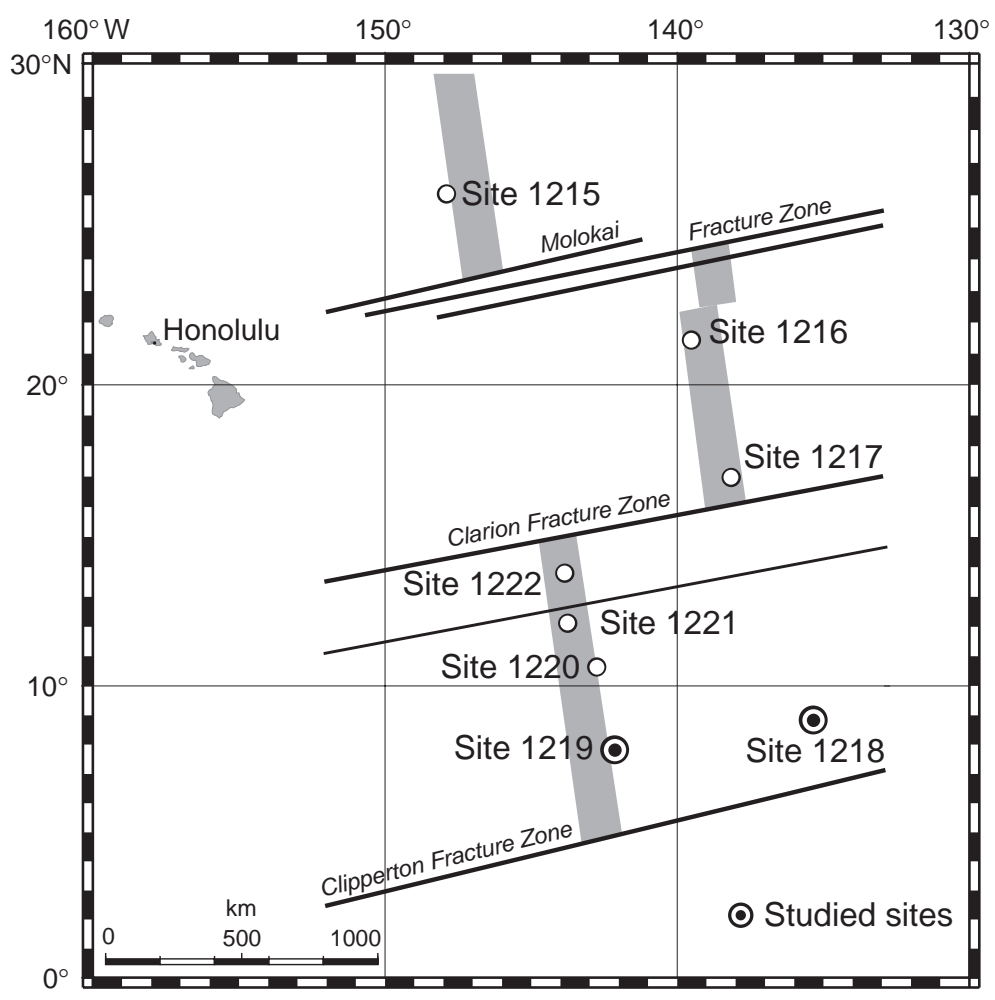

Fig. 1. Location of ODP Sites 1218 and 1219 in the Equatorial Pacific. 
II). A change in lithology from nannofossil ooze to radiolarian clay and clayey radiolarian ooze occurs at $151 \mathrm{mbsf}$ at about the Eocene/Oligocene boundary. Of all sites sampled during ODP Leg 199, Sites 1218 and 1219 have the thickest Oligocene sections because they were located closest to the Oligocene equator. These sites have Oligocene deposition rates that were about 5 times higher than the overlying Miocene brown clay unit. The relatively high sedimentation rate enhances the time resolution of the record; moreover, the carbonate sediments did not suffer noticeable deformation during coring and they optimally preserve the original direction of the natural remanent magnetization (NRM). At both sites, the nannofossil ooze/chalk unit exhibits cyclic variations of carbonate content, probably related to orbitally-driven climate changes, that can be used to construct an orbitally tuned Oligocene age model.

A composite section was constructed shipboard using core-logging data to correlate the cores drilled at Sites 1218 and 1219 and to scale them according to meters composite depth [2]. A revised splice of these sites has been recently compiled that also incorporates shipboard magnetostratigraphic data [20]. The mapping of Site 1219 to Site 1218 results in relative sedimentation rates at Site 1218 that are about $16 \%$ higher than at Site 1219 over the Oligocene interval [2]. The revised mod scale from Pälike et al. [20] (also referred as rmcd) has been used in this paper with small changes restricted to

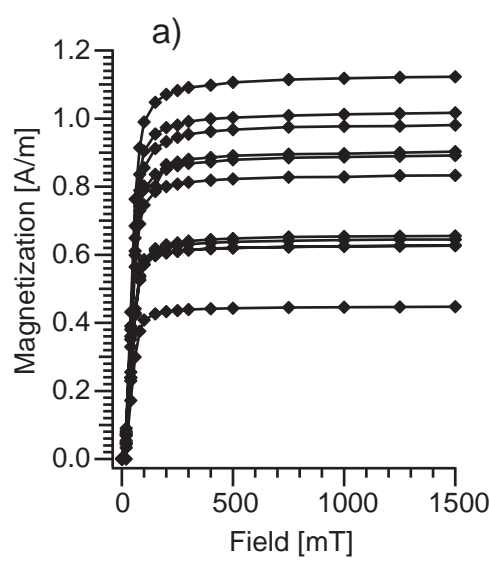

d)

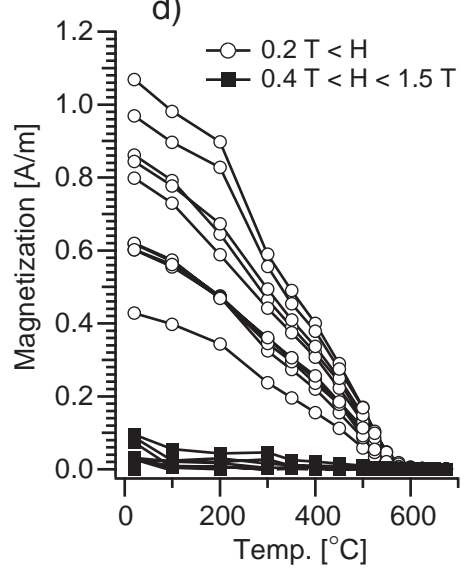

b)

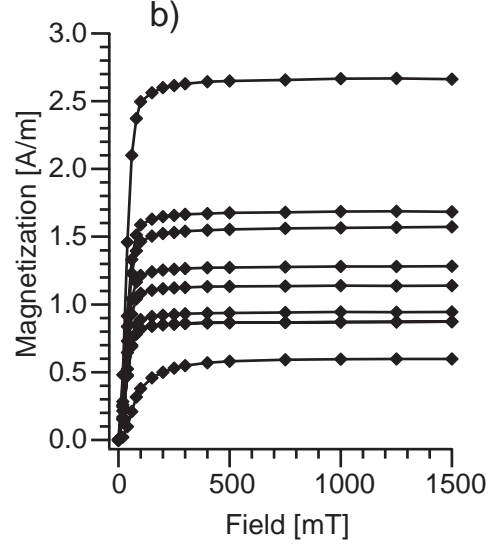

e)

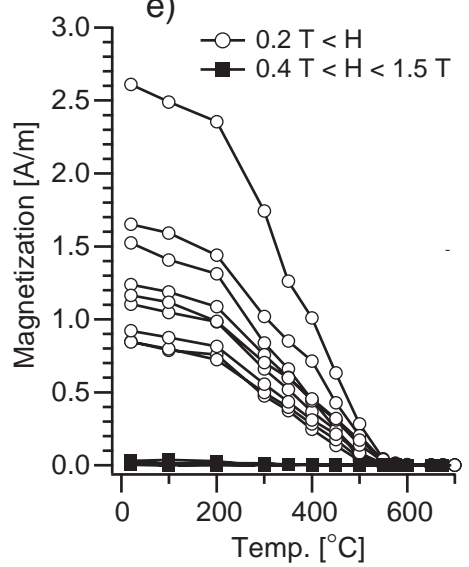

c)

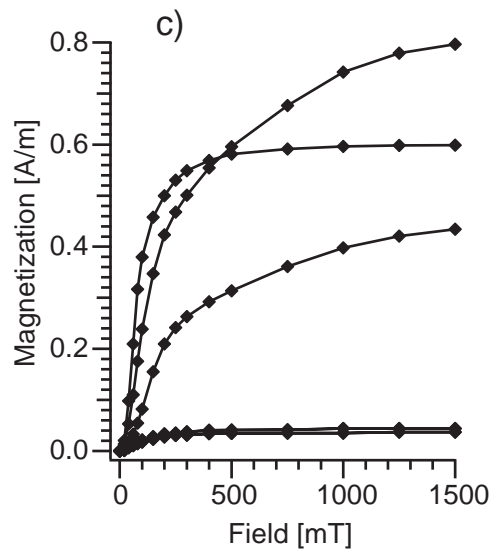

f)

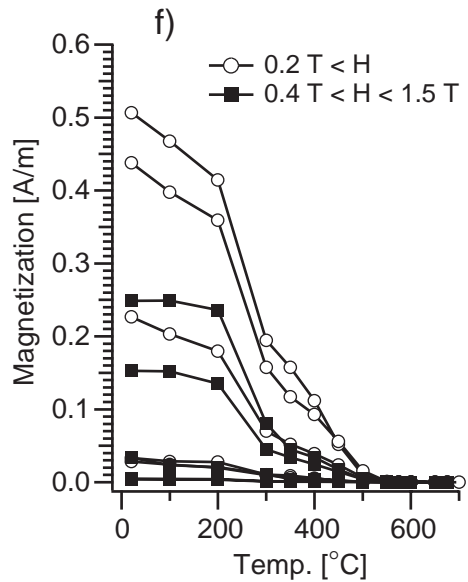

Fig. 2. Progressive IRM acquisition of representative samples from (a) Sites 1218, (b) Site 1219 and (c) upper $7 \mathrm{~m}$ of Site 1219 , which did not yield to reliable results. Panels (d), (e), and (f) show the thermal demagnetization of orthogonal components IRM [24] of sites 1218, 1219 and upper $7 \mathrm{~m}$ of site 1219 , respectively. 

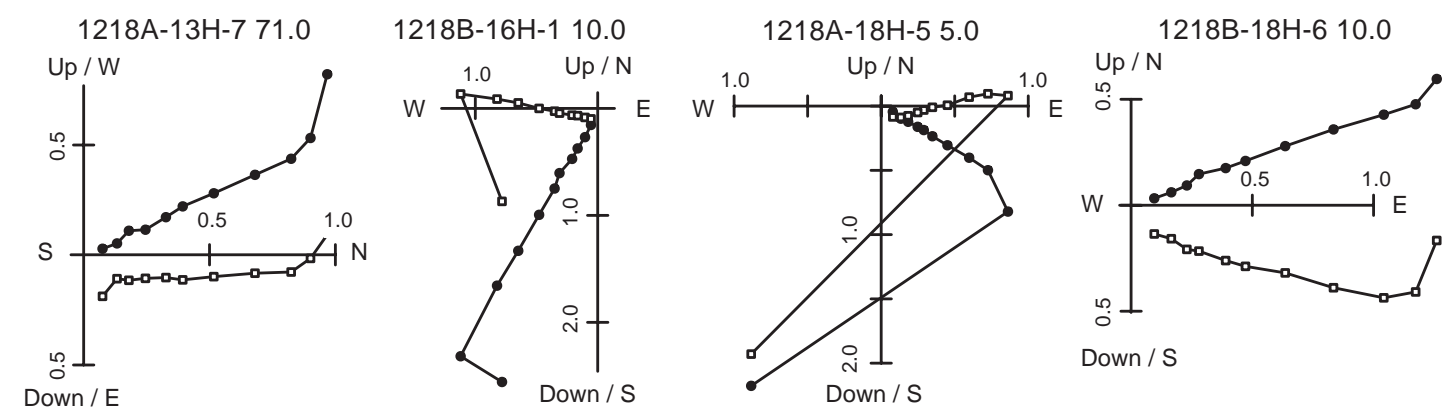

$1218 \mathrm{C}-8 \mathrm{H}-240.0$
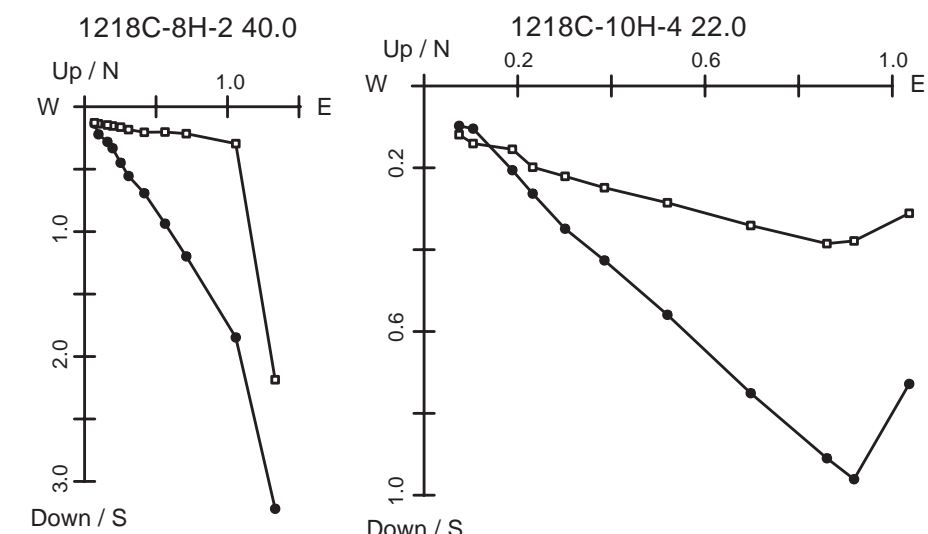

$1218 \mathrm{C}-11 \mathrm{H}-115.0$

Down / S
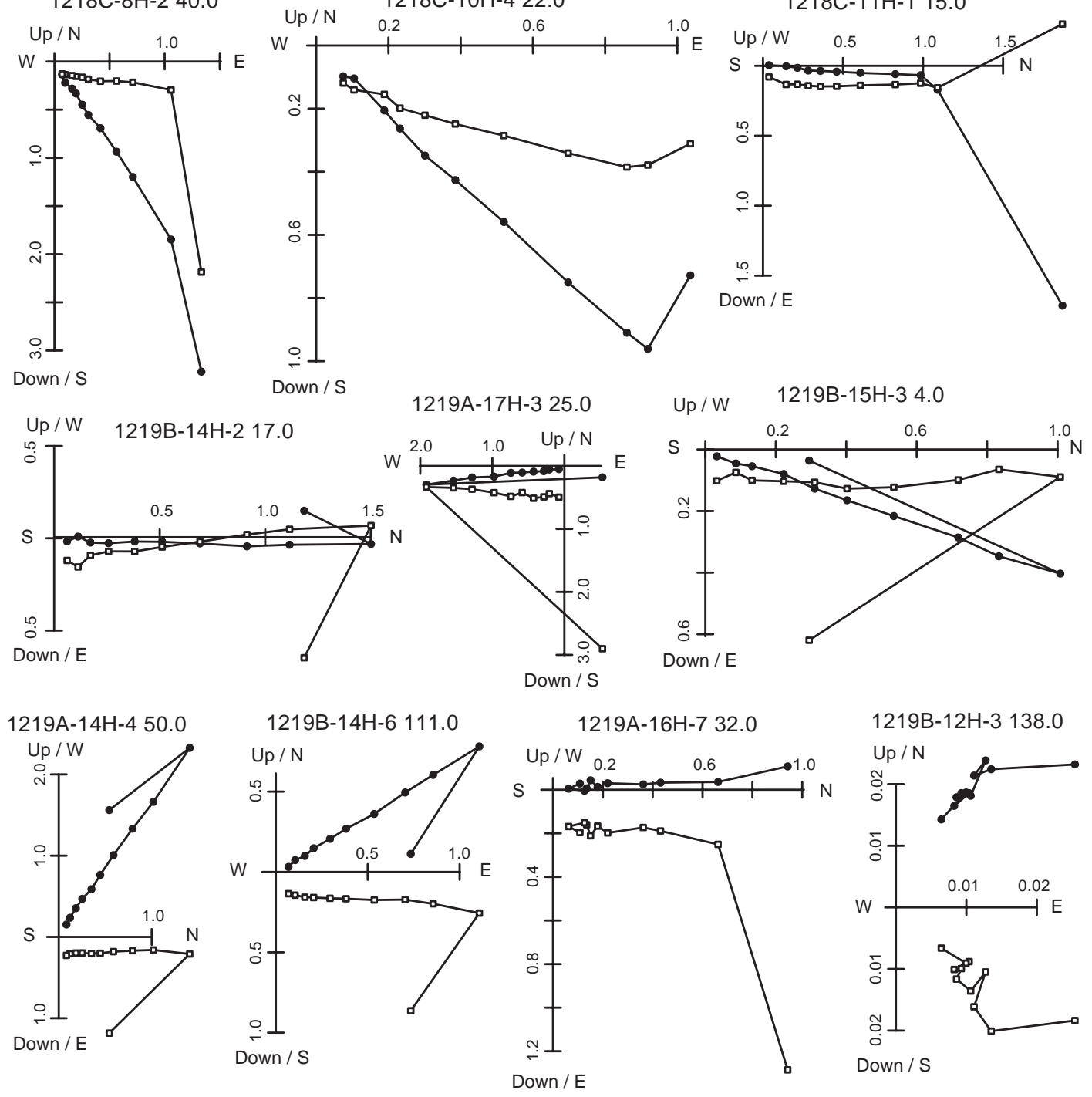

Fig. 3. Typical Zijderveld plots [25] for u-channel data at Sites 1218 and 1219; open and closed symbols represent the vertical and horizontal projections, respectively. The AF demagnetization steps are 0 (NRM), 10, 20, 25, 30, 35, 40, 45, 50, 60, 80 mT in all plots; magnetization units are in $\mathrm{m} \mathrm{A} / \mathrm{m}$. 
a)

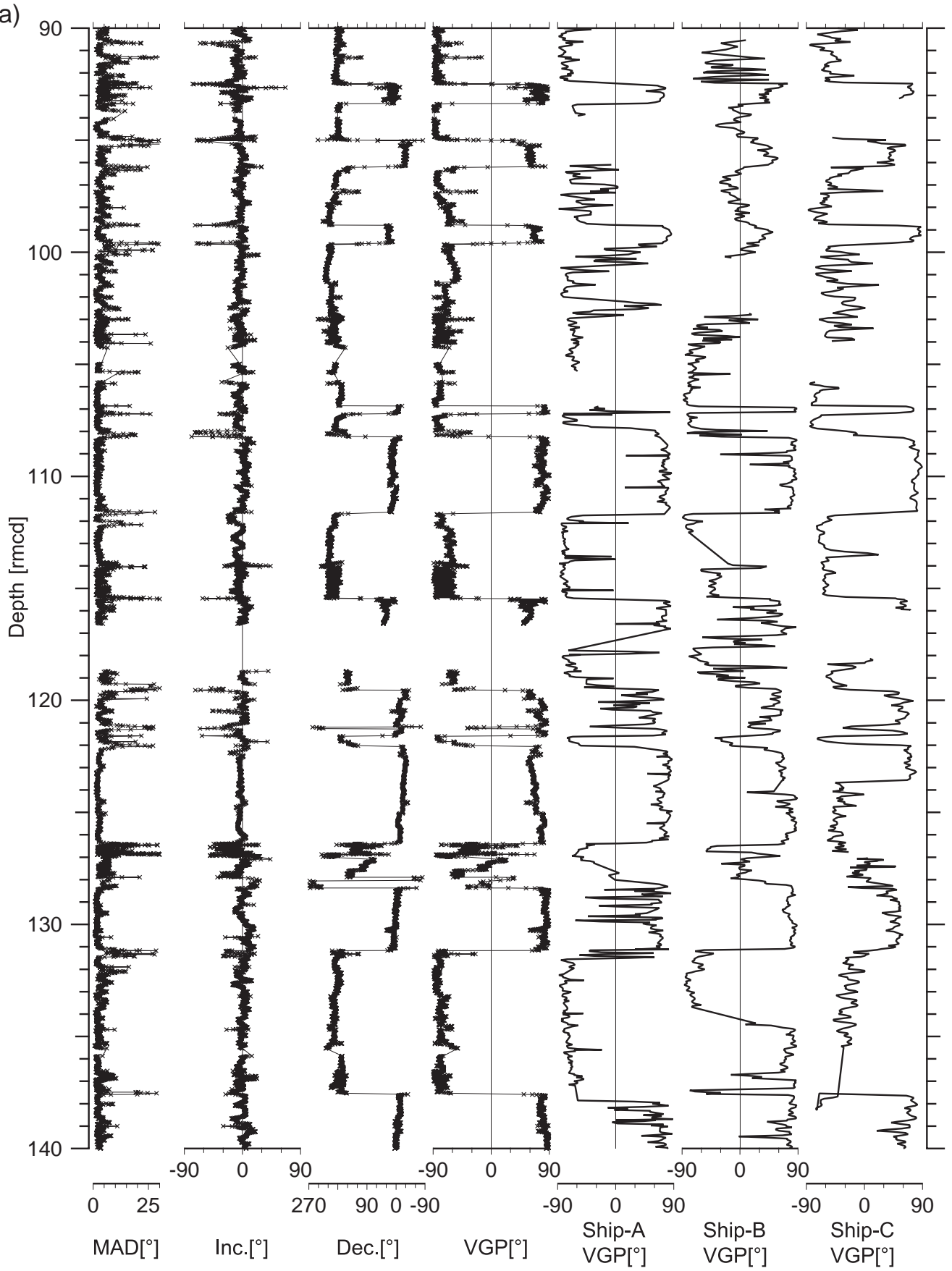

Fig. 4. Paleomagnetic directions, VGP latitude and MAD values for u-channel samples and shipboard measurements for (a, b) Site 1218 and (c) Site 1219. Samples highlighted with the grey band in the top section of (c) did not yield reliable results. Paleomagnetic polarity is interpreted using the VGP latitude, which combines the information from both declination and inclination. 


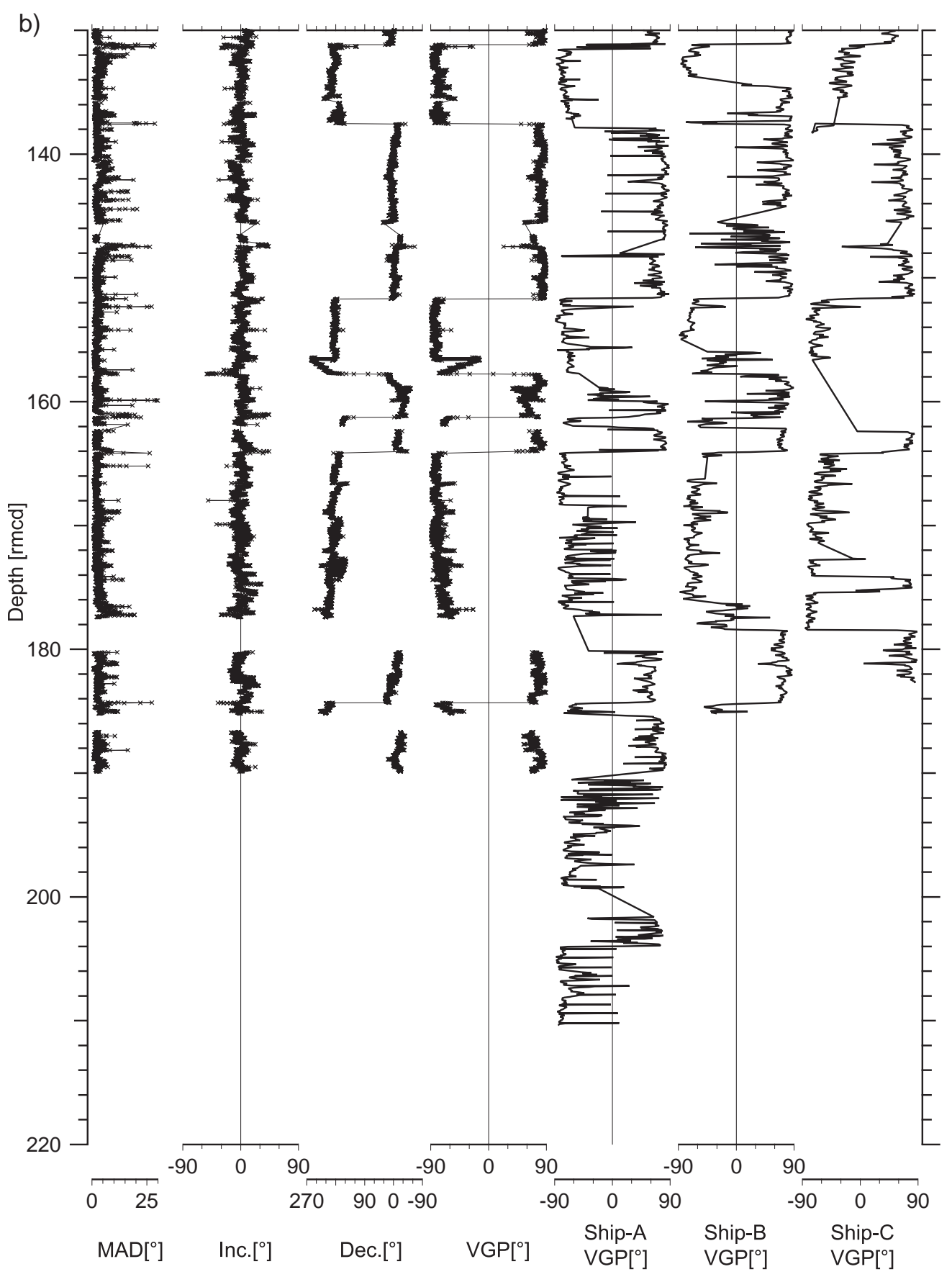

Fig. 4 (continued).

Site 1218 , which are needed to accommodate the higher precision of the u-channel based magnetostratigraphy. For practical reasons we describe all results in the revised mod scale, but the polarity transitions are also reported using the standard ODP notation with Site-Hole-Core number, and position 


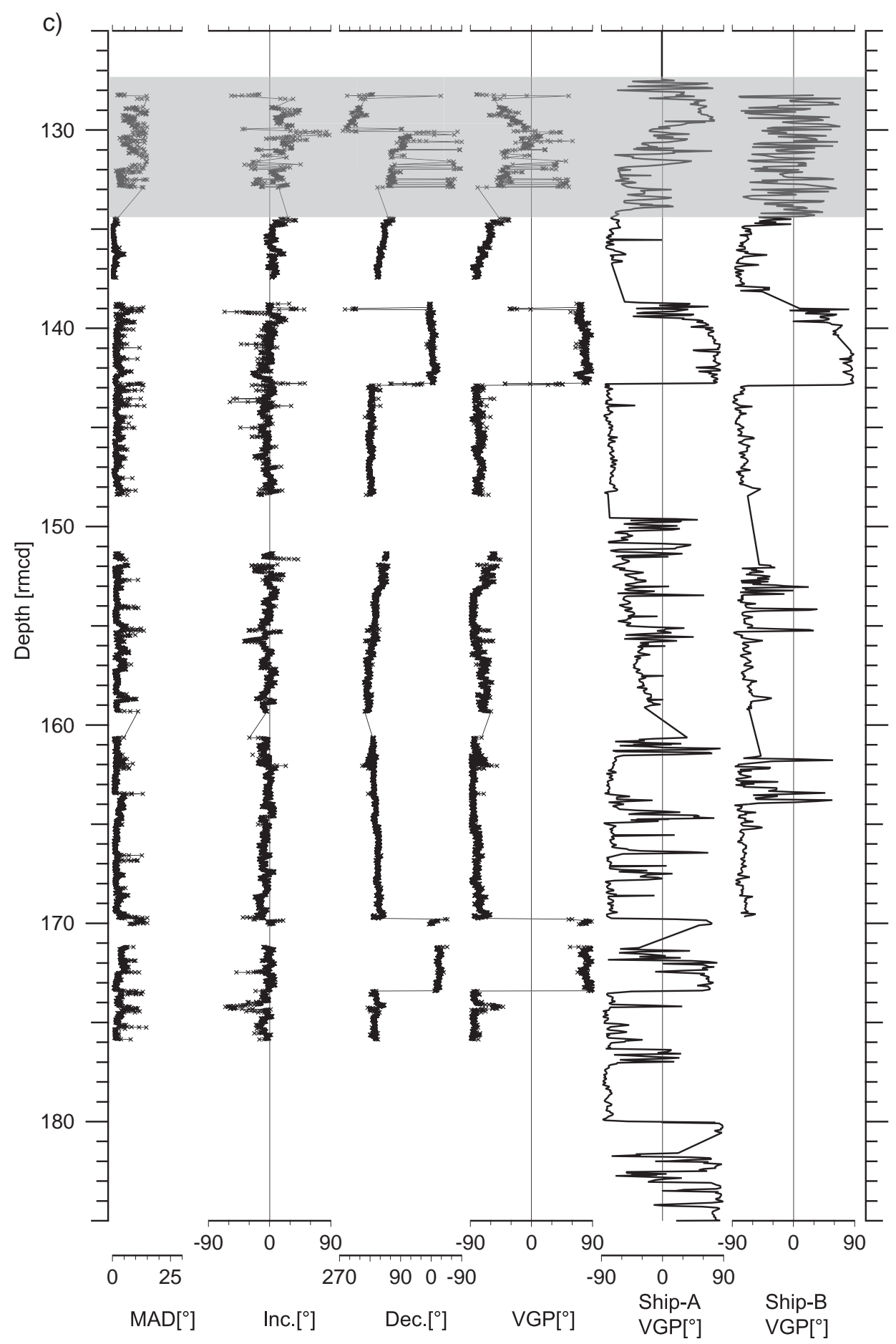

Fig. 4 (continued). 
relative to the core top, to unequivocally identify each level.

\section{Magnetic measurements}

The Oligocene magnetostratigraphy reported here is based on a total of $76 \mathrm{u}$-channel samples from Site 1218 and 32 u-channel samples from Site 1219 that were collected at the Gulf Coast Repository at Texas A\&M University. Each u-channel sample is nominally $1.5 \mathrm{~m}$ in length and $2 \times 2 \mathrm{~cm}$ in cross-section. About 188 discrete samples $\left(7 \mathrm{~cm}^{3}\right.$ of sediment in plastic cubes) from Site 1218 and 33 samples from Site 1219 were $\mathrm{AF}$ demagnetized and measured to corroborate the u-channel data.

\subsection{Magnetic mineralogy}

The magnetic mineralogy of the sediments was studied using isothermal remanent magnetization (IRM) acquisition curves and subsequent thermal demagnetization of orthogonal components [21]. IRMs were progressively acquired up to a maximum field of $1.5 \mathrm{~T}$ in representative samples from Site 1218 (Fig. 2a) and Site 1219 (Fig. 2b and c). The saturation IRM is comparable among the different sites and has a relatively small variability, thus suggesting a low variability of magnetic minerals concentration. With the exception of the upper $7 \mathrm{~m}$ section from Site 1219 (Fig. 2c), IRM acquisition curves are very similar in both sites and are characterized by a predominant low coercivity mineral fraction, which saturates in fields less than $150 \mathrm{mT}$. After IRM acquisition, we applied three orthogonal magnetizations using fields of 1.5, 0.4 and $0.2 \mathrm{~T}$ and subjected the samples to progressive thermal demagnetization. We consider only the low coercivity $(H<0.2 \mathrm{~T})$ and the high coercivity $(H \geq 0.4 \mathrm{~T})$ fractions disregarding the intermediate coercivity component that, in this case, does not give any additional information. Thermal demagnetization of orthogonal IRM (Fig. 2d and e) shows that virtually all the IRM is carried by the low coercivity fraction $H<0.2 \mathrm{~T}$, which has an unblocking temperature between 550 and $600{ }^{\circ} \mathrm{C}$ as expected for magnetite. Samples from the upper part of the Site 1219 section show noticeably different magnetic properties (Fig. 2c and f) that are characterized by lower IRM values and, sometimes, by the presence of a significant fraction of high coercivity minerals that do not saturate at the maximum applied fields. Thermal demagnetization of some of these samples shows that the high coercivity component has an intermediate unblocking temperature of about $400{ }^{\circ} \mathrm{C}$, which suggests the presence of iron sulphides. Except for these samples, the rock magnetic properties of Oligocene samples are virtually identical to those of the Miocene section of Sites 1218 [3], and indicate that the main magnetic carrier is magnetite.

\subsection{NRM measurements}

The natural remanent magnetization (NRM) of u-channel samples was measured at 1-cm intervals and was subjected to progressive alternating field (AF) demagnetization [22]. The measurement spacing was designed to identify cryptochrons and to recognize brief polarity chrons not reported on the standard GPTS. U-channel measurements were made on a $2 \mathrm{G}$ Enterprises DC-SQUID pass-through cryogenic magnetometer at the University of Florida. Discrete samples and rock magnetic analyses were measured at the Lamont-Doherty Paleomagnetics Laboratory and at the Alpine Laboratory of Paleomagnetism at Peveragno (Italy). Demagnetization techniques and procedures are similar to those described for the Miocene section of Site 1218 [3]. Discrete samples were AF demagnetized at the same steps used for the u-channel samples.

NRM intensities in the nannofossil ooze at Site 1218 are about $1 \times 10^{-3} \mathrm{~A} / \mathrm{m}$. The NRM intensities of sediments at Site 1219 are similar except for cores 1219B-12H-1 to $1219 \mathrm{~B}-12 \mathrm{H}-3$, in the upper $7 \mathrm{~m}$ of the sampled interval, where intensities are particularly weak $\left(2-5 \times 10^{-5} \mathrm{~A} / \mathrm{m}\right)$. These intensities are significantly lower than those measured in the upper brown clay unit but they are still well above the background noise level of the DC-SQUID magnetometer.

\section{Paleomagnetic directions}

AF demagnetization of the NRM was effective in the majority of the measured samples. Typical orthogonal vector plots [25] for the Oligocene section of Sites 1218 and 1219 are illustrated in Fig. 3. A low- 
coercivity component, which can be generally removed after AF demagnetization at 10-20 mT, was found in all samples. This component has usually a steep downward direction. At these sites, the attempt of using the declination of the viscous component of NRM to confirm azimuthal orientation of the cores was not successful because we could not define a consistent declination of the low-coercivity component, which may represent a drilling-induced remanence. A linear trend pointing generally toward the origin of the plot is isolated by subsequent demagnetization up to the maximum peak AF of $80 \mathrm{mT}$. This component is interpreted as the characteristic remanent magnetization (ChRM). As already observed in the Miocene section of Site 1218 [3], most of the demagnetization trajectories systematically bypass the origin (equivalent to the presence of a small residual high-coercivity component with a steep downward direction). The origin of this component is attributed to a spurious anhysteretic remanence acquired during AF demagnetization [3]; alternatively it could represent an overprint acquired during storage in the core repository [23]. The presence of this small spurious component could induce a proportionally small bias in the ChRM inclination but it has a negligible effect on virtual geomagnetic pole (VGP) latitude and interpretation of the magnetostratigraphy.

The ChRM directions were calculated from 6 to 8 AF demagnetization steps in the range from 20 $\mathrm{mT}$ to $60 \mathrm{mT}$ using principal component analysis [24]. The quality of the measurements and the linefitting (without anchoring to the origin) was evaluated by visual inspection of the orthogonal vector plots and by calculating the maximum angular deviation (MAD). MAD values are generally low, indicating high data quality; mean MAD is $4.2^{\circ} \pm 2.4^{\circ}$ at Site 1218 and $2.7^{\circ} \pm 1.4^{\circ}$ at Site 1219 . Only a small percentage of samples $(2.9 \%$ at Site 1218 and $1.6 \%$ at Site 1219) have MAD values larger than $15^{\circ}$, which in most cases are associated with polarity transitions and hence could be a consequence of the low NRM intensity and/or rapidly changing directions over these intervals. ChRM directions were azimuthally corrected for core orientation, as obtained from the tensor tool; core orientation methods and related problems are described in Lanci et al. [3].
ChRM directions (declination and inclination), MAD angles, VGP latitudes from u-channel and from shipboard measurements are plotted versus core depth (rmcd) in Fig. 4a and b (Site 1218) and in Fig. 4c, (Site 1219). As expected at these sites for the Oligocene, [26,27], the ChRM inclinations are shallow and are practically indistinguishable from zero, which indicates deposition at equatorial paleolatitudes. High inclinations occur locally during polarity reversals possibly due to transitional directions; other anomalously high inclinations are usually associated with large MAD values.

An interval with anomalous ChRM directions was found at Site 1218 from about 126.5 to $128.5 \mathrm{rmcd}$ (Fig. 4a). Both declinations and inclinations in this interval are inconsistent with the expected values and with measurements from adjacent samples (Fig. 5). The same problem was also observed in shipboard measurements from Holes $\mathrm{A}, \mathrm{B}$ and $\mathrm{C}$ and in one

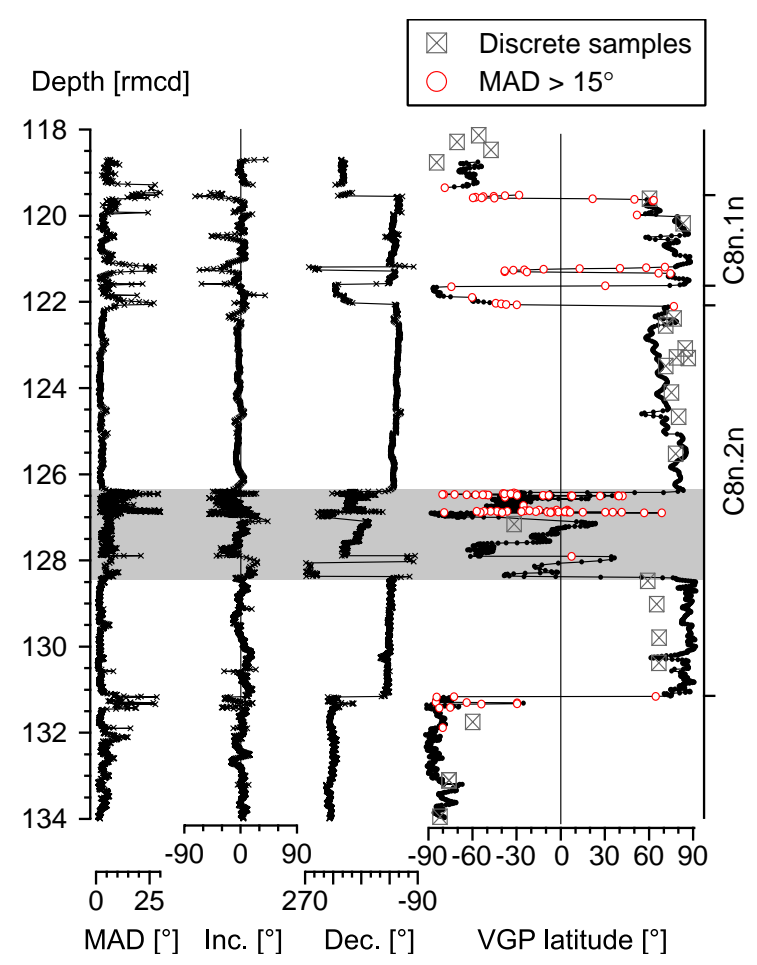

Fig. 5. Details of ChRM directions in Chron C8n. The grey band highlights anomalous directions that do not seem to be related to geomagnetic field behaviour but rather to sediment disturbance. The short reversed polarity interval in chron $\mathrm{C} 8 \mathrm{n} .1 \mathrm{n}$ is also visible at about $121 \mathrm{rmcd}$. 

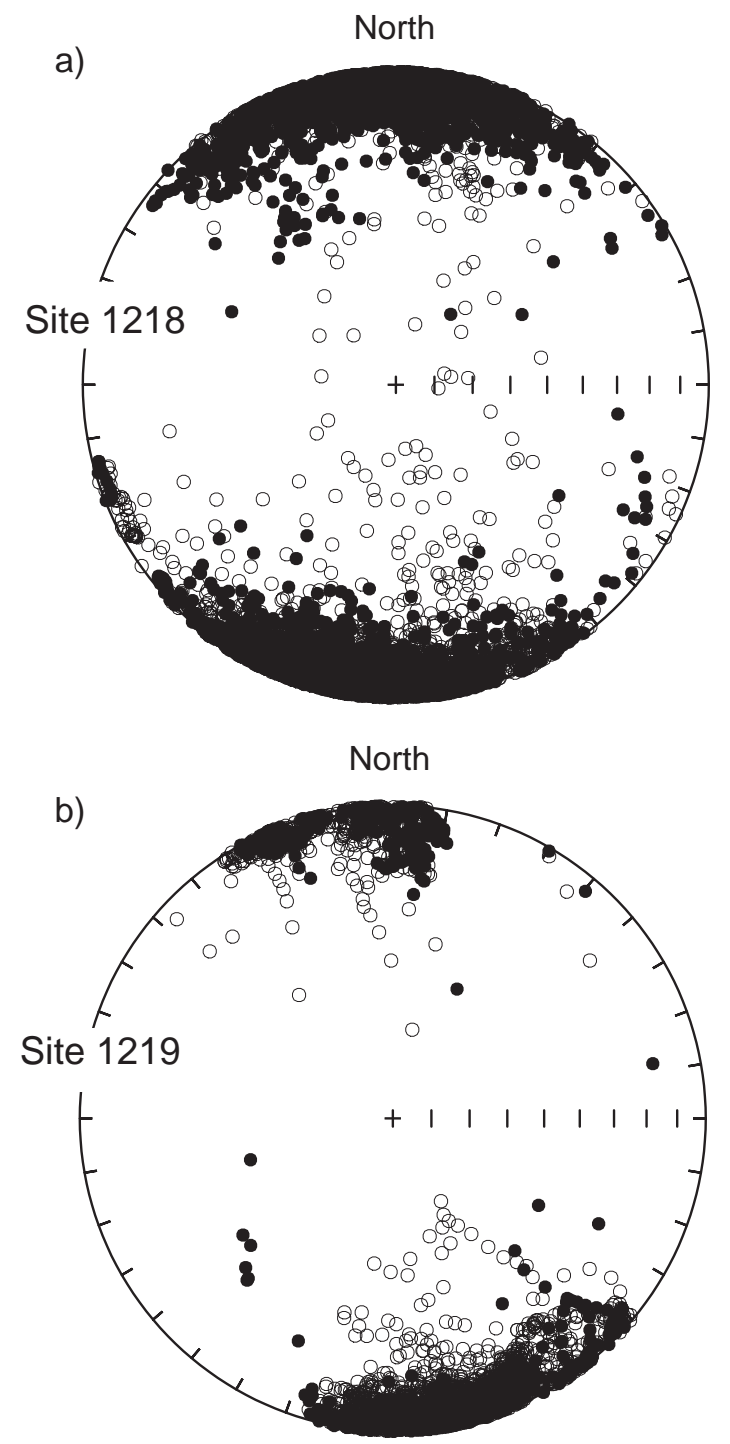

Fig. 6. Equal area projections of the ChRM directions for the Oligocene part of a) Site 1218 and b) Site 1219. Open and closed symbols are projected onto the upper and the lower hemisphere, respectively.

discrete sample taken within this interval. We suggest that the origin of these anomalous directions is related to sediment disturbance. The different thicknesses of the disturbed interval among Holes A, B and C (Fig. $4 a)$ and the rotated declinations with small changes in the inclinations, indicate rotated blocks of sediment and suggest the occurrence of a submarine slide in the sedimentary record.
The only exception to the uniform behaviour of samples from Site 1219 was found in the upper $7 \mathrm{~m}$ of the section sampled at Site 1219. Sediments in this interval are characterized by low NRM intensity (about $9 \times 10^{-5} \mathrm{~A} / \mathrm{m}$ on average) and by the presence of high coercivity minerals, which are interpreted as iron sulphides (Fig. 2c and f). Sample 1219B-12H-3, $138.0 \mathrm{~cm}$ in Fig. 3 is an example of demagnetization behaviour from cores 1219B-12H-1 to 1219B-12H-3. Although in this particular sample the ChRM direction can be estimated, in most cases the ChRM direction is not well defined because of low NRM intensity and high coercivity of the magnetization. For this reason we discarded results from these three core sections (highlighted with the grey band, from $\sim 128$ to 134 rmcd in Fig. 4a) from the magnetostratigraphic interpretation.

ChRM directions are plotted in equal-area projections in Fig. 6. They are well grouped in two antipodal clusters; the few intermediate directions can be attributed to polarity transitions and, at Site 1218 , to the anomalous directions between 126.5 and 128.5 rmcd. Mean directions, which were computed separately for normal and reversed polarity populations, and associated Fisher statistics [28], are shown in Table 1. The mean directions are within $5^{\circ}$ of being antipodal at both sites but fail a reversal test because of the small $\alpha_{95}$ confidence angle related to the large number of samples. Also, failure to pass the reversal test is partly due to declination scatter (especially at Site 1218), which can be a consequence of the low resolution of the

Table 1

Fisher statistics of the ChRM directions at Sites 1218 and 1219

\begin{tabular}{llrllll}
\hline & Dec & \multicolumn{1}{l}{ Inc } & $\alpha_{95}$ & $k$ & $R$ & $N$ \\
\hline Site 1218 Normal & 355.9 & 1.2 & 0.5 & 18.82 & 3948.51 & 4170 \\
Site 1218 Normal & - & 1.2 & 0.3 & 35.2 & - & 4170 \\
Site 1218 Reverse & 186.7 & -2.5 & 0.5 & 17.62 & 4953.09 & 5251 \\
Site 1218 Reverse & - & -2.4 & 0.3 & 35.3 & - & 5251 \\
Site 1219 Normal & 350.4 & -1.8 & 1.1 & 26.07 & 622.22 & 647 \\
Site 1219 Normal & - & -1.6 & 0.9 & 42.7 & - & 647 \\
Site 1219 Reverse & 167.8 & -5.3 & 0.6 & 26.55 & 2396.25 & 2490 \\
Site 1219 Reverse & - & -3.9 & 0.4 & 38.6 & - & 2490 \\
\hline
\end{tabular}

Statistics are computed separately for normal and reversed polarities. Although directions are nearly antipodal they do not fall in the $95 \%$ confidence range of their opposite directions, thus they do not pass a reversal test. Statistics in italics are calculated from inclination only using the inclination-only method of McFadden and Reid [29]. 
core orientation (tensor) tool, which results in an imperfect declination correction. There are, however, statistically significant differences in the mean incli- nation of the normal and reversed polarity groups, especially at Site 1219. Mean inclinations for normal and reversed directions calculated from only the

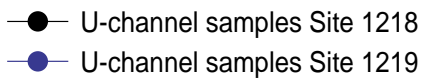

Depth 1218

[rmcd]

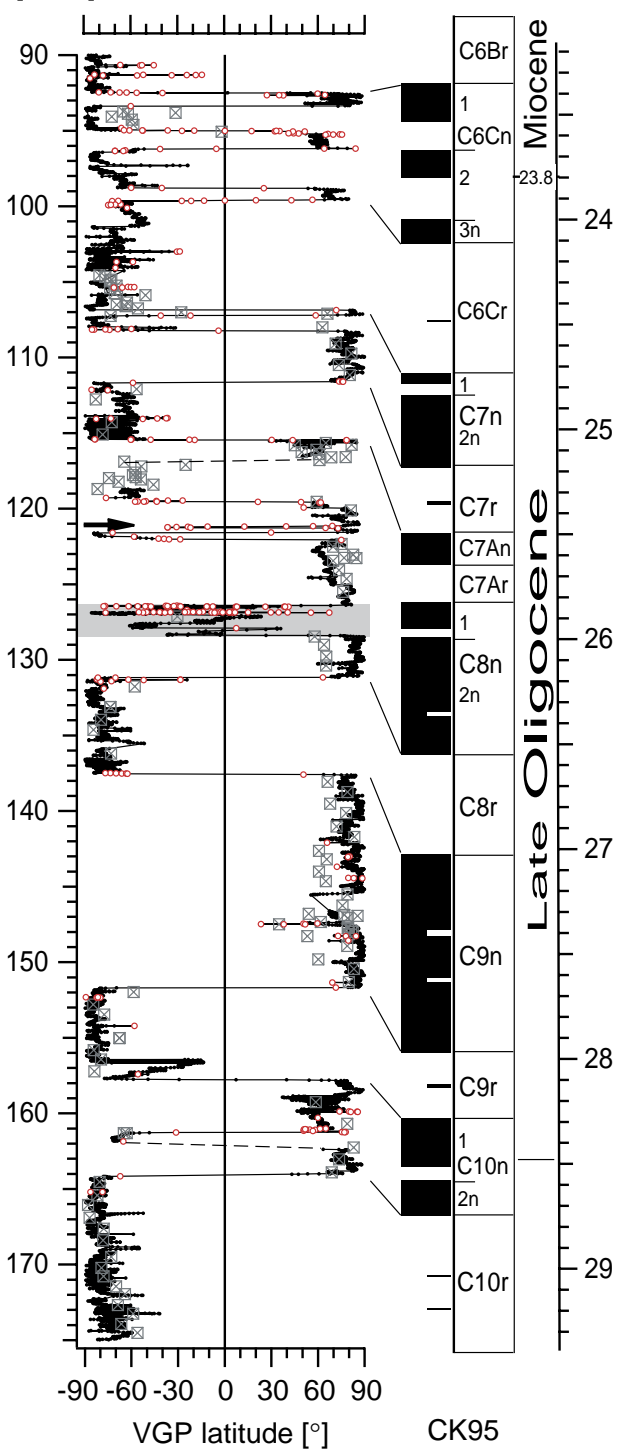

$\triangle$ Discrete samples Site 1219

Discrete samples Site 1219
○ $M A D>15^{\circ}$

$\prec$ Shipboard data

\section{Depth 1218}

[rmcd]
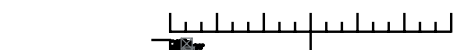
Age $[\mathrm{Ma}]$
$+$

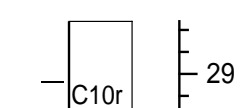

180

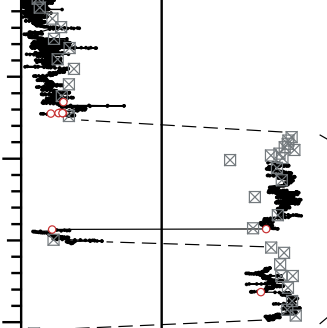

Depth 190

[rmcd]

年

当

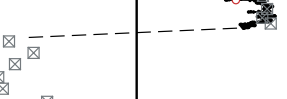

140

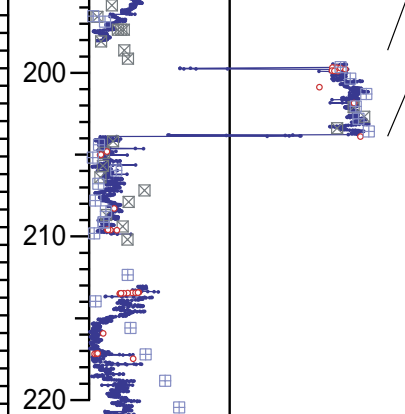

160

$220-$

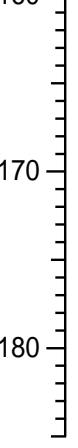

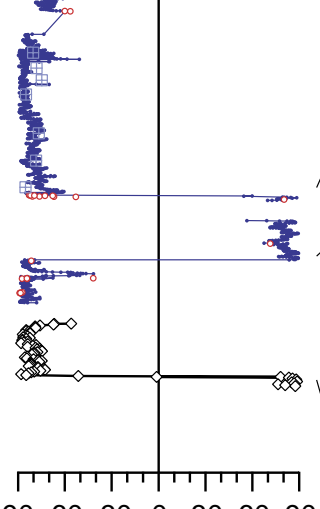

$-90-60-30 \quad 0 \quad 306090$

VGP latitude $\left[^{\circ}\right]$

CK95

Fig. 7. VGP latitude from Site 1218 and Site 1219 correlated with the CK95 polarity time scale. Correlation between Sites 1218 and 1219 is based on magnetostratigraphy. Dashed lines connect reversals identified using discrete samples or they indicate the presence of small gaps in the u-channel record. Both u-channel measurements and discrete samples are plotted versus core depth in rmcd; u-channel samples with MAD values larger than $15^{\circ}$ are marked with open symbols. The grey band from about 127 to 129 rmcd highlights anomalous directions due to sediment disturbance; the arrow at $121 \mathrm{rmcd}$ point to the short reverse polarity interval in chron C8n. $1 \mathrm{n}$. 
inclinations using the method of McFadden and Reid [29], thus disregarding any problem of azimuthal core orientation, do not significantly differ from the standard Fisher means (Table 1). As discussed in Lanci et al. [3], the small bias toward negative inclinations, observed here, may be related to a spurious high-coercivity downward component recognized in the vector plots.

\section{Discussion}

\subsection{Magnetostratigraphy}

The VGP latitudes for Sites 1218 and 1219 are shown in Fig. 7, where they are compared with the GPTS of CK95. It should be noted that depths for Site 1219 were stretched in order to correlate the two sites by matching the length of Chron $\mathrm{C} 12 \mathrm{n}$ measured in $\mathrm{u}-$ channel samples, from Site 1219, and from discrete samples, in Site 1218. This simple correlation, based only on the magnetostratigraphic results, is adequate for this paper and there was no need to transform the site depths to a common scale. With the exception of the short reversed polarity interval within Chron C8n.1n at $121 \mathrm{rmcd}$, all reversals found in the sedimentary record are consistent with CK95, providing an unambiguous correlation that is supported by biostratigraphic data [2]. The age-depth curve (Fig. 8) is smooth with slowly varying sedimentation rates. The average sedimentation rate for the Oligocene section at Site 1218 was about $14 \mathrm{~m} / \mathrm{Myr}$ (Fig. 8), which is significantly higher than that of the Miocene section at the same site [3], which is also plotted for reference. The sedimentation rate during the Early Oligocene at Site 1219 was about $11.5 \mathrm{~m} / \mathrm{Myr}$.

The Oligocene/Miocene boundary in Site 1218 is placed at about $96 \mathrm{rmcd}$ at the onset of chron $\mathrm{C} 6 \mathrm{Cn} .2 \mathrm{n}$ in accordance with the criteria proposed by Berggren et al. [30], and ratified by Steininger et al. [31] at the Oligocene-Miocene boundary stratotype. The Eocene/ Oligocene boundary is placed slightly below the top

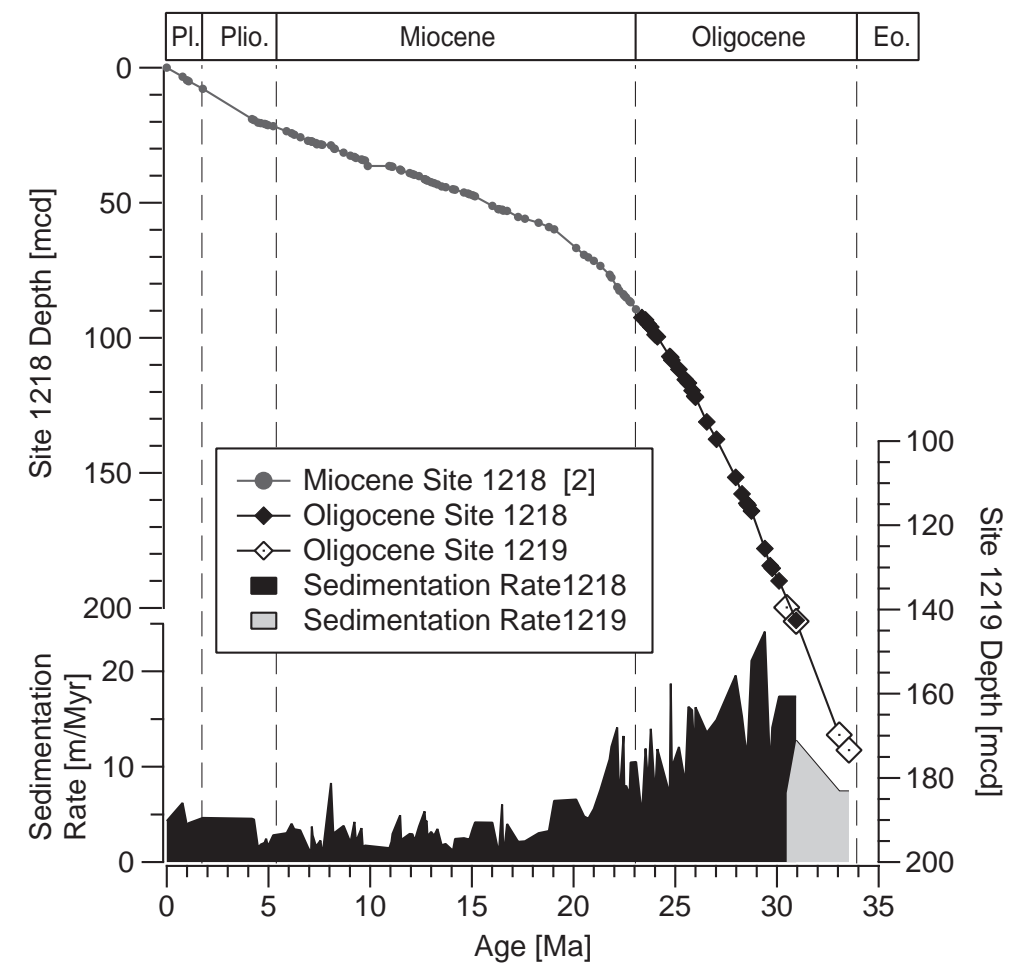

Fig. 8. Age-depth correlation for Sites 1218 and 1219; age is from the CK95 and depth is the stratigraphic (rmcd) depth. Data from our Miocene magnetostratigraphy [3] are also reported for comparison. The average Oligocene sedimentation rate, computed with least-squares line fitting, is about $14 \mathrm{~m} / \mathrm{Myr}$ at Site 1218 and slightly lower at Site 1219 (11.5 m/Myr). 
of Chron $13 \mathrm{r}$ at about $174 \mathrm{rmcd}$ near the base of the section sampled with u-channel at Site 1219 . Both boundaries are placed by correlation with the GPTS.

The positions of the geomagnetic reversals recognized in Fig. 7 are listed in Table 2 using the depth (rmcd) estimates and the standard ODP notation (Hole-Core-Section and position from top of the section) to unequivocally identify the position of the reversal in the core. The range given in Table 2 indicates either the presence of a gap in the sedimentary record or the presence of transitional directions.

\subsection{Comparison with shipboard results and site 1220}

The u-channel-based magnetostratigraphy shows generally good agreement with the shipboard-based results (Fig. 4a,b,c) and the overall interpretation of the magnetic stratigraphy [2] is not changed by the new data. However, compared to shipboard measurements, which are based on blanket demagneti-

Table 2

Depths of reversals found in cores from Sites 1218 and 1219

\begin{tabular}{|c|c|c|c|}
\hline Chron & From [section, cm] & To [section, cm] & Depth [rmcd] \\
\hline \multirow[t]{2}{*}{ C6Cn.1n T } & 1218B-10H-2, 17.0 & 1218B-10H-2, 19.0 & $92.50-92.52$ \\
\hline & $1218 \mathrm{C}-3 \mathrm{H}-6,142.0$ & $1218 \mathrm{C}-3 \mathrm{H}-6,144.0$ & $92.48-92.50$ \\
\hline C6Cn.1n B & 1218B-10H-2, 114.0 & $1218 \mathrm{~B}-10 \mathrm{H}-2,115.0$ & $93.36-93.37$ \\
\hline \multirow[t]{2}{*}{$\mathrm{C} 6 \mathrm{Cn} .2 \mathrm{n} \mathrm{T}$} & $1218 \mathrm{C}-4 \mathrm{H}-1,16.0$ & $1218 \mathrm{C}-4 \mathrm{H}-1,17.0$ & $95.00-95.01$ \\
\hline & 1218A-9H-7, 76.0 & 1218A-9H-7, 78.0 & $95.00-95.02$ \\
\hline $\mathrm{C} 6 \mathrm{Cn} \cdot 2 \mathrm{n} \mathrm{B}$ & $1218 \mathrm{C}-4 \mathrm{H}-1,128.0$ & $1218 \mathrm{C}-4 \mathrm{H}-1,130.0$ & $96.19-96.21$ \\
\hline C6Cn.3n T & $1218 \mathrm{C}-4 \mathrm{H}-3,73.0$ & $1218 \mathrm{C}-4 \mathrm{H}-3,75.0$ & $98.79-98.81$ \\
\hline C6Cn.3n B & $1218 \mathrm{C}-4 \mathrm{H}-3,146.0$ & $1218 \mathrm{C}-4 \mathrm{H}-3,148.0$ & $99.60-99.62$ \\
\hline C7n.1n T & $1218 \mathrm{C}-5 \mathrm{H}-1,112.0$ & $1218 \mathrm{C}-5 \mathrm{H}-1,113.0$ & $106.85-106.86$ \\
\hline C7n.1n B & $1218 \mathrm{C}-5 \mathrm{H}-1,148.0$ & $1218 \mathrm{C}-5 \mathrm{H}-2,02.0$ & $107.20-107.24$ \\
\hline C7n.2n T & $1218 \mathrm{C}-5 \mathrm{H}-2,90.0$ & $1218 \mathrm{C}-5 \mathrm{H}-2,92.0$ & $108.22-108.24$ \\
\hline C7n.2n B & $1218 \mathrm{C}-5 \mathrm{H}-4,111.0$ & $1218 \mathrm{C}-5 \mathrm{H}-4,116.0$ & $111.60-111.67$ \\
\hline C7An T & 1218B-12H-1, 133.0 & $1218 \mathrm{C}-5 \mathrm{H}-6,131.0$ & $115.45-115.46$ \\
\hline \multirow[t]{2}{*}{ C7An B } & 1218B-12H-2, 115.0 & 1218B-12H-2, 125.0 & 116.79-116.89 \\
\hline & $1218 \mathrm{C}-5 \mathrm{H}-7,78.0$ & $1218 \mathrm{C}-6 \mathrm{H}-1,49.0$ & $116.58-118.69$ \\
\hline C8n. $\ln T$ & $1218 \mathrm{C}-6 \mathrm{H}-1,116.0$ & $1218 \mathrm{C}-6 \mathrm{H}-1,117.0$ & $119.54-119.55$ \\
\hline C8n.1n B & $1218 \mathrm{C}-6 \mathrm{H}-2,129.0$ & $1218 \mathrm{C}-6 \mathrm{H}-2,130.0$ & $121.59-121.60$ \\
\hline $\mathrm{C} 8 \mathrm{n} .2 \mathrm{n} T$ & $1218 \mathrm{C}-6 \mathrm{H}-3,14.0$ & $1218 \mathrm{C}-6 \mathrm{H}-3,17.0$ & $122.03-122.06$ \\
\hline C8n.2n B & $1218 \mathrm{C}-7 \mathrm{H}-4,68.0$ & $1218 \mathrm{C}-7 \mathrm{H}-4,69.0$ & $131.16-131.17$ \\
\hline $\mathrm{C} 9 \mathrm{n} \mathrm{T}$ & $1218 \mathrm{C}-8 \mathrm{H}-2,05.0$ & $1218 \mathrm{C}-8 \mathrm{H}-2,09.0$ & $137.54-137.58$ \\
\hline C9n B & $1218 \mathrm{C}-9 \mathrm{H}-4,36.0$ & $1218 \mathrm{C}-9 \mathrm{H}-4,38.0$ & $151.68-151.70$ \\
\hline C10n.1n T & 1218B-16H-2, 34.0 & 1218B-16H-2, 36.0 & $157.76-157.78$ \\
\hline C10n.1n B & $1218 \mathrm{~A}-16 \mathrm{H}-2,92.0$ & $1218 \mathrm{~A}-16 \mathrm{H}-2,94.0$ & $161.25-161.27$ \\
\hline C10n.2n T & 1218A-16H-2, 150.0 & $1218 \mathrm{C}-10 \mathrm{H}-1,04.0$ & $161.85-162.38$ \\
\hline C10n.2n B & $1218 \mathrm{C}-10 \mathrm{H}-2,23.0$ & $1218 \mathrm{C}-10 \mathrm{H}-2,37.0$ & $164.02-164.15$ \\
\hline C11n.1n T & $1218 \mathrm{~A}-17 \mathrm{H}-7,85.0$ & 1218C-11H-5, 07.0 & 177.41-178.69 \\
\hline C11n.1n B & 1218B-18H-,-61.0 & 1218B-18H-6, 63.0 & $184.31-184.33$ \\
\hline $\mathrm{C} 11 \mathrm{n} .2 \mathrm{n} \mathrm{T}$ & 1218B-18H-6, 145.0 & $1218 \mathrm{~A}-18 \mathrm{H}-4,17.0$ & 185.19-185.43 \\
\hline C11n.2n B & 1218A-18H-7, 10.0 & 1218A-19H-1, 60.0 & $189.59-190.68$ \\
\hline \multirow[t]{2}{*}{$\mathrm{C} 12 \mathrm{n} T$} & 1218A-19H-7, 50.0 & 1218A-20H-1, 61.0 & 199.14-202.09 \\
\hline & 1219B-12H-6W, 150.0 & 1219A-14H-1, 16.0 & $137.45-138.77$ \\
\hline \multirow[t]{2}{*}{$\mathrm{C} 12 \mathrm{n} B$} & 1218A-20H-2, 41.0 & 1218A-20H-2-121.0 & 203.39-204.19 \\
\hline & 1219A-14H-3, 126.0 & 1219A-14H-3, 136.0 & $142.77-142.87$ \\
\hline \multirow[t]{2}{*}{$\mathrm{C} 13 \mathrm{n} \mathrm{T}$} & 1219A-16H-7, 13.0 & 1219A-16H-7, 20.0 & $169.73-169.80$ \\
\hline & 1219B-15H-6, 140.0 & & $169.75-$ \\
\hline C13n B & 1219A-17H-2, 92.0 & 1219A-17H-2, 93.0 & $173.42-173.43$ \\
\hline
\end{tabular}

Depths are reported as rmcd (modified from [20]) and the sample intervals are identified with the ODP naming convention (hole-core-sectioninterval). Boldface text refers to discrete samples. The range indicated is due either to gaps in the record, or to transitional directions. Depths (in rmcd) are obviously different for the two sites. 
zation at peak fields of $20 \mathrm{mT}$, the new data are more robust and have higher resolution. The higher spatial resolution of u-channel data results from the closer measurement steps and from the narrower response function of the u-channel pass-through magnetometer compared to the shipboard passthrough magnetometer that was designed for measurements of whole and half cores. Polarity transitions are sharp in u-channel measurements and occur mostly within $1-3 \mathrm{~cm}$ stratigraphic intervals compared to the $10-15 \mathrm{~cm}$ intervals estimated from shipboard measurements. Stepwise demagnetization and PCA analysis have greatly improved the reliability of the magnetostratigraphy and resulted in removal of many spurious measurements. In Chron $\mathrm{C} 12 \mathrm{r}$, for instance, the shipboard-VGP latitude values are much noisier than the results from u-channel measurements (Fig. 4c).

Comparison of the reversal polarity sequence from Sites 1218/1219 with the nearby Site 1220 [4] is straightforward. All the major features of the GTPS are found at both sites with the sole exception of Chron C7n.1n, which was not found in Site 1220, and they can be easily correlated (Fig. 9). Despite the similar magnetostratigraphy, lithology and sedimentation rate constitute important differences between the two sites. The siliceous sedimentation at Site 1220 has an average sedimentation rate of about $5 \mathrm{~m} / \mathrm{Myr}$, which is significantly lower than the average of $13 \mathrm{~m} / \mathrm{Myr}$ at Sites 1218/1219 and constituted a major limitation in searching for shortlived polarity chrons at Site 1220. A theoretical model of post-depositional remanent magnetization from Roberts and Winklhofer [32] has shown that the probability to record short polarity chrons is strongly dependent on sedimentation rate. This model applied to the sedimentation rate of Site 1220 suggests that even under the best conditions (i.e., with a median lock-in depth of $10 \mathrm{~cm}$ ), this site may be unable to record polarity reversals shorter than about $20 \mathrm{kyr}$, which could explain why no new short polarity chrons were found at this site [4].

\subsection{Short polarity chrons and cryptochrons}

One short polarity interval, which is not reported in the GTPS of Cande and Kent [1], has been identi-

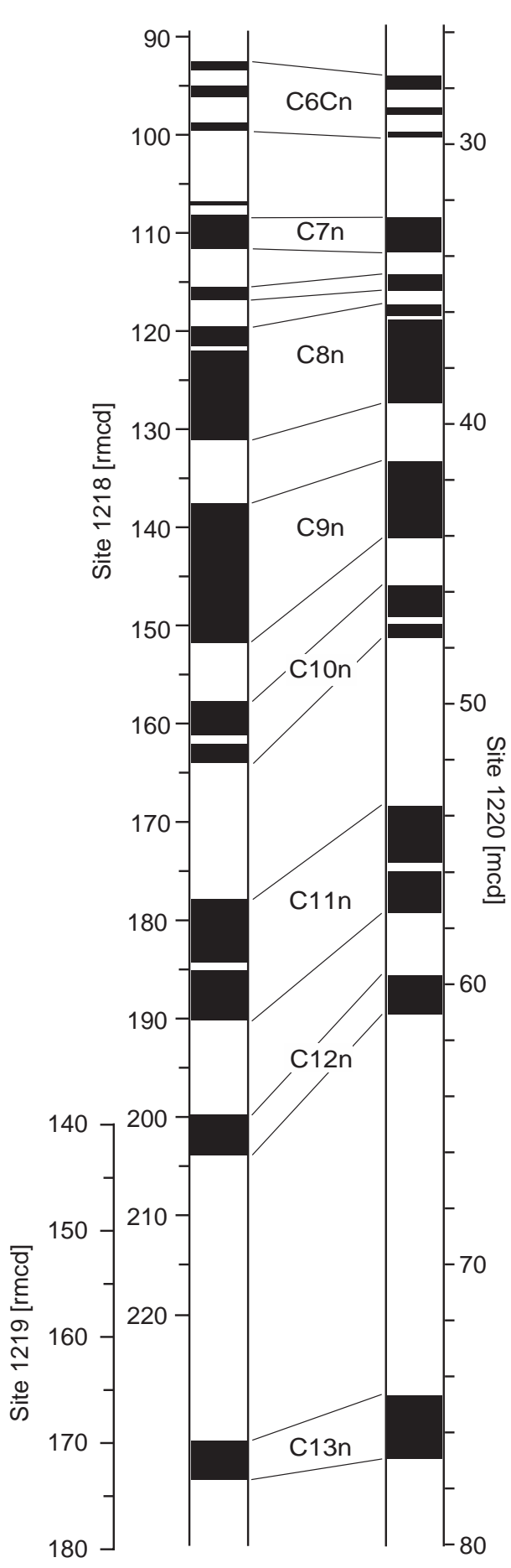

Fig. 9. Correlation of the Oligocene magnetostratigraphic columns from Sites 1218 and 1219 (this work) and from Site 1220. 
fied at Site 1218, within Chron C8n.1n at a depth of about 121.2 rmcd. Details of ChRM directions recorded in this short polarity chron are shown in Fig. 10; although the MAD values are larger than $15^{\circ}$, the vector component plots suggest that a nearly complete polarity reversal occurred. The thickness of this short polarity chron is about $12 \mathrm{~cm}$; based on the assumption of a constant sedimentation rate within Chron C8n.1n, and taking the duration of Chron C8n.1n from CK95, its duration is estimated to be about 7.5 kyr. We are not aware of any other record that can be correlated with this short subchron, therefore it remains to be confirmed whether it represents a real geomagnetic feature or a local sedimentological artefact.

Cryptochrons have been recognized and correlated in many marine magnetic anomaly profiles and are thus thought to represent true features of the main dipole field. In the record from Sites 1218 and 1219, none of the 18 cryptochrons reported by Cande and Kent [8] between chrons C6Cn and C13n corresponds to polarity subchrons; the only new polarity subchron found was the short reversed polarity interval within Chron C8n.1n. According to Cande and Kent $[1,8]$ cryptochrons have durations of about $30 \mathrm{kyr}$ and less. The sedimentary records from Sites 1218 and 1219

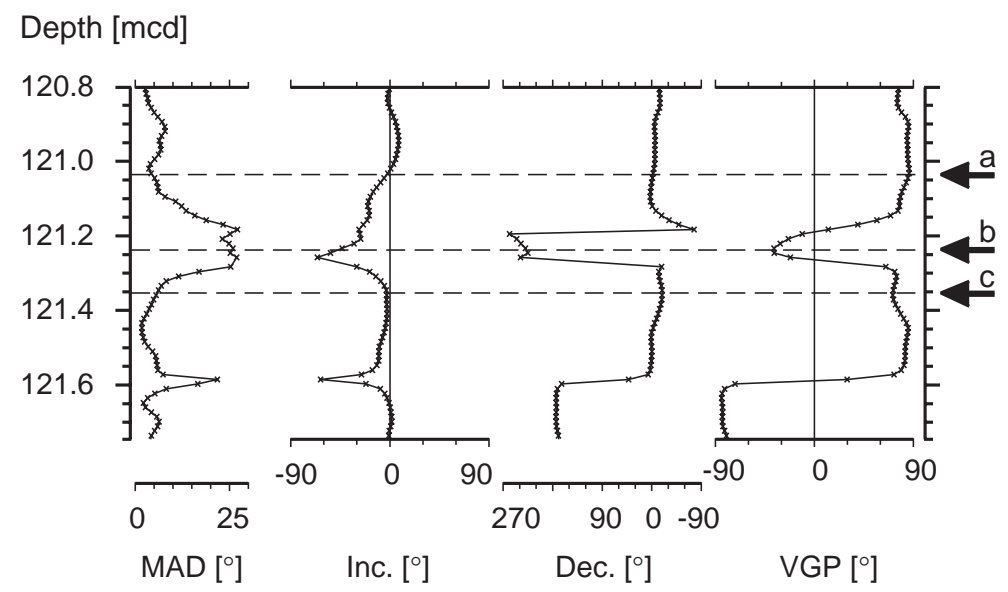

a)

1218C-6H-2 85.0 b) 1218C-6H-2 100.0 c)

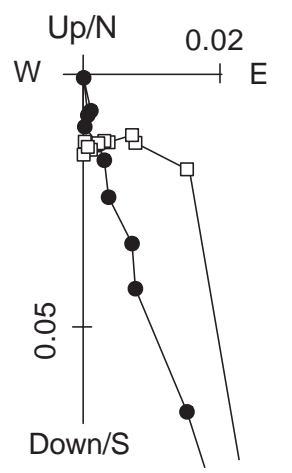

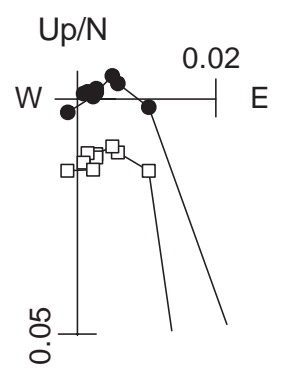

Down/S
$1218 \mathrm{C}-6 \mathrm{H}-2110.0$

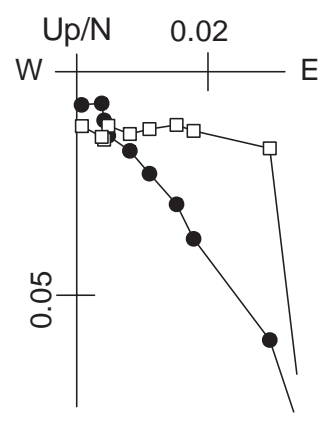

Down/S

Fig. 10. Details of the short polarity chron found within chron C8n.1n. Zijderveld plots for 3 levels (a) before, (b) during and (c) after the event, are also shown. Although the MAD values are large and the NRM intensities are low during the reverse polarity interval, the magnetization directions appear to have completely reversed polarity compared to nearby samples. AF demagnetization fields are 10, 20, 25, 30, 35, 40, 45, 50, $60,80 \mathrm{mT}$ in all Zijderveld plots; magnetization units are $\mathrm{m} \mathrm{A} / \mathrm{m}$. 
have the demonstrated capability to resolve polarity zones of only $5 \mathrm{~cm}$ in thickness [3], which at the average sedimentation rate for these sites translates to the ability to resolve polarity zones with a duration of about 3.5 and $4.5 \mathrm{kyr}$ at Sites 1218 and 1219, respectively. Such a resolution limit is in reasonable agreement with the prediction from theoretical modelling of post-depositional remanent magnetization [32] and it is significantly lower than that estimated from nearby ODP Site 1220.

\section{Conclusion}

Overall, the paleomagnetic record from Site 1218 combined with that of Site 1219 provides a detailed magnetostratigraphy for the entire Oligocene. The magnetostratigraphy is seemingly complete, with only minor gaps in the sedimentary record, and it correlates well with the reversal record from marine magnetic anomalies (CK95). Unambiguous correlation of the magnetostratigraphy to the geomagnetic polarity time scale (CK95) allows robust dating of the sedimentary sequence at the studied sites, which will provide the basis for further refinements based on cyclostratigraphy and astrochronology.

Despite the high resolution of the Site 1218/1219 magnetostratigraphic record, no short polarity chrons have been found that can be related to the cryptochrons reported in the CK95 time scale. The magnetostratigraphy at Site 1218 indicates that these sediments are able to resolve polarity intervals as short as 4-5 kyr [3]. Only a single short polarity subchron is found in the Oligocene section of Site 1218 (within Chron C8n.1n), which has an estimated duration of about $7.5 \mathrm{kyr}$, but requires confirmation. Based on our observations, we conclude that if cryptochrons in the Oligocene do represent geomagnetic polarity chrons, their duration must be less than $\sim 5$ kyr.

\section{Acknowledgments}

We are grateful to Phil Rumford and Bruce Horan at the Gulf Coast Repository, who were very helpful and patient with core sampling. A. Roberts and an anonymous reviewer greatly helped to improve the manuscript. This research used samples provided by the Ocean Drilling Program (ODP). The ODP is sponsored by the U.S. National Science Foundation (NSF) and participating countries under management of Joint Oceanographic Institutions (JOI), Inc. Funding for this research was provided by USSAC. LDEO contribution \#6798.

\section{References}

[1] S.C. Cande, D.V. Kent, Revised calibration of the geomagnetic polarity time scale for the Late Cretaceous and Cenozoic, J. Geophys. Res. 100 (1995) 6093-6095.

[2] Shipboard Scientific Party, Leg 199 summary, in: M.W. Lyle, P.A. Wilson, T.R. Janecek, et al. (Eds.), Proc. ODP, Init. Repts., vol. 199, Ocean Drilling Program, College Station, TX, 2002, pp. 1-87.

[3] L. Lanci, J.-M. Parés, J.E.T. Channell, D.V. Kent, Miocene magnetostratigraphy from Equatorial Pacific sediments (ODP Site 1218, Leg 199), Earth Planet. Sci. Lett. 226 (2004) 207-224.

[4] J.M. Pares, L. Lanci, A complete Middle Eocene-Early Miocene magnetic polarity stratigraphy in Equatorial Pacific sediments (ODP Site 1220), in: J.E.T. Channell, W. Lowrie, D.V. Kent, J. Meert (Eds.), Timescales of the Paleomagnetic Field, AGU Geophysical Monograph Series, vol. 145, American Geophysical Union, Washington, D.C., 2004, pp. 131-140.

[5] J.L. LaBrecque, D.V. Kent, S.C. Cande, Revised magnetic polarity time scale for Late Cretaceous and Cenozoic time, Geology 5 (1977) 330-335.

[6] R.J. Blakely, Geomagnetic reversals and crustal spreading rates during the Miocene, J. Geophys. Res. 79 (1974) 2979-2985.

[7] S.C. Cande, J.L. LaBrecque, Behaviour of the earth's palaeomagnetic field from small scale marine magnetic anomalies, Nature 247 (1974) 26-28.

[8] S.C. Cande, D.V. Kent, Ultra-high resolution marine magnetic anomaly-profiles: a record of continuous paleointensity variations? J. Geophys. Res. 97 (1992) 15075-15083.

[9] E.A. Mankinen, J.M. Donnelly, C.S. Gromme, Geomagnetic polarity event recorded at $1.1 \mathrm{my} \mathrm{BP}$ on Cobb mountain, Clear Lake volcanic field, California, Geology 6 (1978) $653-656$.

[10] E.A. Mankinen, C.S. Gromme, Paleomagnetic data from the Coso Range, California and current status of the Cobb Mountain normal geomagnetic polarity event, Geophys. Res. Lett. 9 (1982) 1279-1282.

[11] I. McDougall, N.D. Watkins, Age and duration of the reunion geomagnetic polarity event, Earth Planet. Sci. Lett. 19 (1973) $443-452$.

[12] F.H. Chamalaun, I. McDougall, Dating geomagnetic polarity epochs in reunion, Nature 210 (1966) 1212-1214.

[13] L. Lanci, W. Lowrie, Magnetostratigraphic evidence that 'tiny wiggles' in the oceanic magnetic anomaly record represent geomagnetic paleointensity variations, Earth Planet. Sci. Lett. 148 (1997) 581-592. 
[14] J.E.T. Channell, S. Galeotti, E.E. Martin, K. Billups, H. Scher, J.S. Stoner, Eocene to Miocene magnetostratigraphy, biostratigraphy, and chemostratigraphy at ODP Site 1090 (sub-Antarctic South Atlantic), Geol. Soc. Amer. bull. 115 (2003) 607-623.

[15] A.P. Roberts, J.C. Lewin-Harris, Marine magnetic anomalies: evidence that 'tiny wiggles' represent short-period geomagnetic polarity intervals, Earth Planet. Sci. Lett. 183 (2000) $375-388$.

[16] H.F. Evans, J.E.T. Channell, Late Miocene magnetic stratigraphy from ODP Site 1092 (sub-Antarctic South Atlantic): recognition of "cryptochrons" in C $5 n .2 n$, Geophys. J. Int. 153 (2003) 483-496.

[17] H.F. Evans, T. Westerhold, J.E.T. Channell, ODP Site 1092: revised composite depth section has implications for Upper Miocene "cryptochrons", Geophys. J. Int. 156 (2004) 195-199.

[18] W. Krijgsman, D.V. Kent, Non-uniform occurrence of shortterm polarity fluctuations in the geomagnetic field? New results from Middle to Late Miocene sediments of the North Atlantic (DSDP Site 608), in: J.E.T. Channell, W. Lowrie, D.V. Kent, J. Meert (Eds.), Timescales of the Paleomagnetic Field, AGU Geophysical Monograph Series, vol. 145, American Geophysical Union, Washington, D.C., 2004, pp. 161-174.

[19] J. Bowles, L. Tauxe, J. Gee, D. McMillan, S. Cande, Source of tiny wiggles in Chron C5: a comparison of sedimentary relative intensity and marine magnetic anomalies, Geochem. Geophys. Geosyst. 4 (6) (2003) 1049, doi:10.1029/2002GC000489.

[20] H. Pälike, T. Moore, J. Backman, I. Raffi, L. Lanci, J.M. Parés, T. Janecek, Integrated stratigraphic correlation and improved composite depth scales for ODP Sites 1218 and 1219, in: P.A. Wilson, M. Lyle, J.V. Firth (Eds.), Proc. ODP, Sci. Results, vol. 199, 2005.

[21] W. Lowrie, Identification of ferromagnetic minerals in a rock by coercivity and unblocking temperature properties, Geophys. Res. Lett. 17 (1990) 159-162.

[22] R. Weeks, C. Laj, L. Endignous, M. Fuller, A. Roberts, R. Manganne, E. Blanchard, W. Goree, Improvements in longcore measurement techniques: applications in palaeaomagnetism and palaeoceanography, Geophys. J. Int. 114 (1993) $651-662$.
[23] Y. Touchard, P. Rochette, M.P. Aubry, A. Michard, Highresolution magnetostratigraphic and biostratigraphic study of Ethiopian traps-related products in Oligocene sediments from the Indian Ocean, Earth Planet. Sci. Lett. 206 (2003) 493-508, doi:10.1016/S0012-1821X(1002) (01084-01081).

[24] J.L. Kirschvink, The least-squares line and plane and the analysis of palaeomagnetic data, Geophys. J. R. Astron. Soc. 62 (1980) 699-718.

[25] J.D.A. Zijderveld, A.C. demagnetization of rocks - analysis of results, in: D.W. Collinson, K.M. Creer, S.K. Runcorn (Eds.), Methods in Paleomagnetism, Elsevier, New York, 1967, pp. 254-286.

[26] A.E. Gripp, R.G. Gordon, Current plate velocities relative to the hotspots incorporating the NUVEL-1 global plate motion model, Geophys. Res. Lett. 17 (1990) 1109-1112.

[27] D.C. Engebretson, A. Cox, R.G. Gordon, Relative motions between oceanic and continental plates in the Pacific Basin, Spec. Pap. - Geol. Soc. Am. 206 (1985)1953.

[28] R.A. Fisher, Dispersion on a Sphere R. Soc. of London, vol. A217, 1953, pp. 295-305.

[29] P.L. McFadden, A.B. Reid, Analysis of palaeomagnetic inclination data, Geophys. J. R. Astron. Soc. 69 (1982) 307-319.

[30] W.A. Berggren, D.V. Kent, C.C. Swisher, M.P. Aubry, A revised Cenozoic geochronology and chronostratigraphy in time scales and global stratigraphic correlations: a unified temporal framework for an historical geology, Geochronology, Time-Scales, and Stratigraphic Correlation, SEPM Spec. Publ., vol. 54, 1995, pp. 129-212.

[31] F.F. Steininger, M.P. Aubrey, M. Biolzi, A.M. Borsetti, F. Cati, F. Corfield, R. Gelati, S. Iaccarino, G. Napoleone, F. Rogl, R. Rotzel, S. Spezzaferri, F. Tateo, G. Villa, D. Zevenboom, Proposal for the global stratotype section and point (GSSP) for the base of the Neogene (the Paleogene/Neogene boundary), in: A. Montanari, G.S. Odin, R. Coccioni (Eds.), Miocene Stratigraphy: An Integrated Approach, Elsevier, Amsterdam, 1977, pp. 124-147.

[32] A.P. Roberts, M. Winklhofer, Why are geomagnetic excursions not always recorded in sediments? Constraints from post-depositional remanent magnetization lock-in modelling, Earth Planet. Sci. Lett. 227 (2004) 345-359. 